Mehmet Yildirimel, Mehmet Nuri Atalar, Sedat Abusoglu, Duygu Eryavuz Onmaz*, Abdullah Sivrikaya, Gulsum Abusoglu and Ali Unlu

\title{
Measurement of serum creatinine levels with liquid chromatography-tandem mass spectrometry: comparison with Jaffe and enzymatic methods
}

\section{Serum kreatinin seviyelerinin sıvı kromatografi- tandem kütle spektrometresi ile ölçülmesi: Jaffe ve enzimatik yöntemlerle karşılaştırılması}

https://doi.org/10.1515/tjb-2019-0357

Received August 27, 2019; accepted January 31, 2020;

published online July 27,2020

\begin{abstract}
Objectives: Our aim was to validate a mass spectrometric creatinine method and compare this method with Jaffe and enzymatic serum creatinine methods.

Methods: 90 samples were included. The levels were classified into three groups according to serum creatinine results as Group 1: Lower $(\mathrm{n}=30)(0.16-0.59 \mathrm{mg} / \mathrm{dL})$, Group 2: Normal $(\mathrm{n}=30)(0.62-1.18 \mathrm{mg} / \mathrm{dL})$ and Group 3: Higher $(\mathrm{n}=30)(1.33-3.88 \mathrm{mg} / \mathrm{dL})$. Jaffe and enzymatic creatinine measurements were performed on the Beckman Coulter AU5800 autoanalyzer.
\end{abstract}

Results: Serum creatinine was linear from 0.039 up to $10 \mathrm{mg} / \mathrm{dL}, \mathrm{CV}$ and bias values were ranged between $1.9-3.8 \%$ and $2-15 \%$. Correlation coefficients were 0.990 (95\% confidence interval 0.984-0.993), 0.992 (95\% confidence interval 0.988-0.995) and 0.994 (95\% confidence

*Corresponding author: Duygu Eryavuz Onmaz, Selcuk University Faculty of Medicine, Department of Biochemistry, Konya, Turkey, E-mail: duygu_eryavuz@hotmail.com

Mehmet Yildirimel, Sedat Abusoglu, Abdullah Sivrikaya and Ali Unlu: Selcuk University Faculty of Medicine, Department of Biochemistry, Konya, Turkey. https://orcid.org/0000-0002-2984-0527 (S. Abusoglu)

Mehmet Nuri Atalar: Igdir University, Faculty of Science and Letters, Department of Biochemistry, Igdir, Turkey

Gulsum Abusoglu: Selcuk University Vocational School of Health, Department of Medical Laboratory Techniques, Konya, Turkey. https://orcid.org/0000-0003-1630-1257 interval 0.991-0.996) for LC-MS/MS-Enzymatic, LC-MS/ MS-Jaffe and Enzymatic-Jaffe, respectively.

Conclusions: Although, Jaffe method for serum creatinine measurement is still much more practical and cheap, so in use for routine practice, tandem mass spectrometric detection of serum creatinine can be used as an accurate and specific method for verification of discordant clinical results, existence of possible interferences and serum levels under $0.5 \mathrm{mg} / \mathrm{dL}$ creatinine results such as pediatric or pregnant populations.

Keywords: comparison; creatinine; enzymatic; Jaffe; LC-MS/MS

\section{Özet}

Amaç: Böbrek yetmezliğinin erken tespiti, tedavinin uygun şekilde başlatılması için önemlidir. Amacımız kütle spektrometrik kreatinin yöntemini doğrulamak ve bu yöntemi Jaffe ve enzimatik serum kreatinin yöntemleriyle karşılaştırmaktı.

Gereç ve Yöntemler: Çalışmada 90 serum örneği kullanılmıştır. Serum kreatinin sonuçlarına göre düzeyler Grup 1: Düşük (n=30) (0.16-0.59 mg/dL), Grup 2: Normal ( $\mathrm{n}=30)$ $(0.62-1.18 \mathrm{mg} / \mathrm{dL})$ ve Grup 3: Yüksek ( $\mathrm{n}=30)(1,33-3,88 \mathrm{mg} /$ $\mathrm{dL}$ ) olmak üzere 3 'e ayrıldı. Jaffe ve enzimatik yöntemle kreatinin düzeyleri Beckman Coulter AU5800 otoanalizöründe ölçüldü.

Bulgular: Serum kreatinin ölçümü 0.039 mg/dL'den $10 \mathrm{mg} / \mathrm{dL}$ 'ye kadar doğrusaldı, CV ve bias değerleri \% 1.9-3.8 ile \% 2-15 arasında değişmekteydi. Korelasyon katsayıları, LC-MS/MS-Enzimatik, LC-MS / MS-Jaffe ve 
Enzymatic-Jaffe için sırasıyla 0.990 (95\% güven aralığı 0.984 to 0.993 ), 0.992 (95\% güven aralığ1 0.988 to 0.995 ) and 0.994 (95\% güven aralığ1 0.991 to 0.996$)$ olarak hesaplandi.

Sonuç: Serum kreatinin ölçümü için Jaffe yöntemi hala çok daha pratik ve ucuz olmasına rağmen, rutin uygulama için kullanımda, serum kreatininin tandem kütle spektrometrik tespiti interferans olasılığının varlığı, pediyatrik veya hamile popülasyonlar gibi $0,5 \mathrm{mg} / \mathrm{dL}$ kreatinin seviyelerinin altındaki serum seviyeleri ile ilişkili uyumsuz klinik sonuçların doğrulanması için kesin ve spesifik bir yöntemdir.

Anahtar Kelimeler: kreatinin; LC-MS/MS; enzimatik; Jaffe; karşılaştırma.

\section{Introduction}

Glomerular filtration rate has been defined as the best indicator of renal function in disease and health for many years. The actual glomerular function is obscure and estimated values are in use via analysis of some endogenous compounds, such as creatinine [1]. Thus, serum creatinine measurements in clinical laboratories are of great importance. Serum creatinine is measured by a colorimetric method called Jaffe. This reaction based on the yelloworange color formation of picric acid is vulnerable to interference with some chromogens, including bilirubin, proteins, acetoacetate, drugs (cefazolin), glucose and ascorbic acid [2]. Isotope dilution-mass spectrometry (IDMS) traceable methods such as compensated Jaffe or enzymatic creatinine measurement have been developed to address these interferences and improve precision and reduce the bias [3]. Despite these technical improvements, the pitfalls in creatinine measurement could not be overwhelmed. Therefore, high performance liquid chromatography was considered as an alternative technique. However, there were main disadvantages of this method such as matrix-based interferences at ultraviolet (UV) wavelength and time-consuming and labor intensive preanalytical processes [4]. Liquid-chromatography mass spectrometry (LC-MS/MS) provides high selectivity, high throughput and sensitivity for the measurement of molecules in clinical laboratories [5]. Therefore, methods of creatinine analysis in urine [6], dried blood spot [7] and serum samples [8] have been reported in the literature.

In this study, our aim was to partially validate a mass spectrometric creatinine method and compare this method with Jaffe and enzymatic serum creatinine methods by using National Institute of Standards and Technology
(NIST) 914a standard reference material. In our best knowledge, this will be the first national mass spectrometric serum creatinine validation study in our country using clinical samples.

\section{Materials and methods}

In the first part of the study, random serum samples were collected from a biochemistry laboratory. The levels were classified into three groups according to serum creatinine results as Group 1: Lower $(\mathrm{n}=30)$ $(0.16-0.59 \mathrm{mg} / \mathrm{dL})$, Group 2: Normal $(\mathrm{n}=30)(0.62-1.18 \mathrm{mg} / \mathrm{dL})$ and Group 3: Higher $(\mathrm{n}=30)(1.33-3.88 \mathrm{mg} / \mathrm{dL})$. At the second part, pre$(n=20)$ and post- $(n=20)$ dialysis blood samples from the same individuals were collected into biochemistry tubes for creatinine measurement from dialysis patients admitted to Nephrology Clinic of Selcuk University Faculty of Medicine Hospital between MAY 2016August 2016 for routine medical examination and were centrifuged at a 3,500 $\mathrm{g}$ for $10 \mathrm{~min}$. The study was conducted with the residual serum samples of these patients. Jaffe and enzymatic creatinine measurements were performed on the Beckman Coulter AU5800 autoanalyzer (Ref: OSR61204 and Ref: A60298, respectively). This study is confirmed by the local ethics committee (Selcuk University Faculty of Medicine Ethics Committee (Number: 2016/6; Date: 30/03/2016). In Jaffe analysis, creatinine reacts with picric acid in alkaline medium (creatinine plus picric acid creatinine picrate complex) to form a yellow-orange compound. The rate of change in $520 / 800 \mathrm{~nm}$ is proportional to the amount of creatinine in the sample. In the enzymatic analysis, creatinine is hydrolyzed with creatinease and converted into sarcosine and urea. Oxidative demethylation of sarcosine with catalysis of sarcosinoxidase produces glycine, formaldehyde and hydrogen peroxide. In the presence of peroxidase (POD), the hydrogen peroxide present in the medium reacts with $\mathrm{N}$ - (3-sulfopropyl) -3-methoxy-5-methylaniline (HMMPS) and 4-aminoantipyrine to form blue pigment. The creatinine concentration is proportional to the change in absorbance at 600/ $700 \mathrm{~nm}$.

\section{Chemicals and solutions}

Creatinine stock solution was prepared $10.2 \mathrm{mg}$ lyophilized creatinine standard of Sigma-Aldrich brand (Lot no: NIST 914aTA $2555 \mathrm{~V}$ ) was dissolved in $10 \mathrm{~mL}$ of 50\% acetonitrile in water and stock solution of 1,000 ppm (parts per million) was prepared. Various concentrations (100, 50 and $25 \mathrm{ppm}$ ) were prepared by appropriately diluting the stock solution with $50 \%$ acetonitrile/water. The creatinine- $d_{3}$ internal standard (Cambridge Isotope Laboratories, Inc. Lot: PR17756, U.S.A) was dissolved in $100 \mathrm{mg}$ creatinine internal standard with $1 \mathrm{~mL}$ of $50 \%$ acetonitrile/water and creatinine- $\mathrm{d}_{3}$ stock solution of $10,000 \mathrm{ng} / \mathrm{mL}$ was prepared. $5,000 \mathrm{ng} / \mathrm{mL}$ solution was prepared by diluting the stock solution with $50 \%$ acetonitrile/water. The mobile phase consists of $499 \mathrm{~mL}$ of HPLC grade water and $499 \mathrm{~mL}$ of acetonitrile and $2 \mathrm{~mL}$ of formic acid to form the mobile 
phase of 50\% acetonitrile (Sigma Cat No: $34888-\mathrm{M}$ ) with HPLC Grade water (Sigma Cat No: 270733) containing 0.2\% formic acid (Sigma Cat No: 5438040100).

Bovine Serum Albumin-Standard Buffer (BSA-PBS), 0.1 M PBS (Sigma Cat No: P3873), 1\% BSA (Sigma Cat No: A2153), $0.9 \% \mathrm{NaCl}$ (Sigma Cat No: S9888) solution, $1.134 \mathrm{~g} \mathrm{Na}_{2} \mathrm{HPO}_{4}$ (Sigma Cat No: 7907), $0.302 \mathrm{~g} \mathrm{Na}_{2} \mathrm{HPO}_{4}$. $2 \mathrm{H}_{2} \mathrm{O}$ (Sigma Cat No: 04272), $0.9 \mathrm{~g} \mathrm{NaCl}, 1 \mathrm{~g}$ bovine serum albumin (Sigma Cat No: A2153) were dissolved in $100 \mathrm{~mL}$ HPLC grade water. The $\mathrm{pH}$ was adjusted to 7.4 using $\mathrm{NaOH}$ (Sigma Cat No: 221465) and HCl (Sigma Cat No: 320331).

\section{Sample preparation and LC-MS/MS analysis}

$100 \mu \mathrm{L}$ of the sample or standard was pipetted into the eppendorf, $20 \mu \mathrm{L}$ of internal standard $(5,000 \mathrm{ng} / \mathrm{mL}$ creatinine- $d_{3}$ ) and $200 \mu \mathrm{L}$ of $100 \%$ acetonitrile were added. The mixture was vortexed for $10 \mathrm{~s}$ and centrifuged at 13,000 $\mathrm{g}$ for $5 \mathrm{~min}$. After centrifugation, $20 \mu \mathrm{L}$ of the supernatant were injected into Luna $5 \mu 100 \mathrm{~A}, \mathrm{C}$, $50 \times 4.6 \mathrm{~mm}$ (Phenomenex, Torrance, USA) with a $0.6 \mathrm{~mL}$ per minute isocratic mobile phase flow of LC-MS/MS system. Optimization of creatinine measurements were performed by infusion of creatinine standard reference material (SRM) in 50\% acetonitrile/HPLC grade water with $0.2 \%$ formic acid in multiple reaction monitoring (MRM) mode. The intensity of Q1 and Q3 ions were determined via electrospray ionization (ESI) by Auto Tune algorithm in API 3200 (ABSCIEX, Ontario, Canada) tandem mass spectrometry device. The Q1 and Q3 ions with the highest intensity were determined as 114.1/44 for creatinine and $117.1 / 47$ for isotope (creatinine- $d_{3}$ ), respectively. Optimization parameters were determined as: Declustering potential (DP):20; Entrance Potential (EP):10; Collision Energy (CE):35; Collision Cell Exit Potential (CXP):4; Curtain Gas (CUR):20; Collision Gas (CAD):6; Ionspray Voltage (IS):5,500 V (Positive mode); Temperature (TEM):550 ${ }^{\circ} \mathrm{C}$; Ion Source Gas1 (GS1):40; Ion Source Gas2 (GS2):60; Dwell Time:250 ms. Total analysis time was $6 \mathrm{~min}$.

\section{Method validation}

The linearity study carried out within the scope of method validation was performed according to CLSI EP06-A protocol. According to this protocol, $10 \mathrm{mg} / \mathrm{dL}$ of creatinine standard was used in the linearity study by serial dilution with BSA to obtain $5 \mathrm{mg} / \mathrm{dL}, 2.5 \mathrm{mg} / \mathrm{dL}, 1.25 \mathrm{mg} / \mathrm{dL}$, $0.625 \mathrm{mg} / \mathrm{dL}, 0.312 \mathrm{mg} / \mathrm{dL}$ and $0.156 \mathrm{mg} / \mathrm{dL}$. Limits of detection and quantitation were determined according to the CLSI C50A protocol. Recovery, freeze and thaw, stability studies were performed with three different concentrations of serum creatinine such as low $(0.25 \mathrm{mg} / \mathrm{dL})$, middle $(1 \mathrm{mg} / \mathrm{dL})$ and high $(10 \mathrm{mg} / \mathrm{dL})$ according to the CLSI EP6-A Protocol. Interference study was performed with cefazolin, ceftriaxone and glucose according to the CLSI EP7-A protocol. Carryover, matrix effect, reference range verification, precision studies for creatinine were performed according to the CLSI EP10-A3, CLSI EP14-A2, CLSI EP28-A3c protocols and CLSI EP05-A2, respectively [9]. Thus, 40 serum samples from 20 healthy female and male were analyzed by LC-MS/MS method, and the obtained results were compared with the creatinine reference ranges of the Mayo Medical Laboratory. The reference intervals of serum creatinine were $0.8-1.3 \mathrm{mg} / \mathrm{dL}$ for adult male $(n=20)$, and $0.6-1.1 \mathrm{mg} / \mathrm{dL}$ for adult female $(\mathrm{n}=20)$.

\section{Statistical analysis}

Statistical analysis was conducted by using the MedCalc version 9.2.0.1 statistics program, Excel (2011) and SPSS v20. Passing-Bablok regression analysis and Bland-Altman plots were used for comparison of LC-MS/MS, Jaffe and Enzymatic methods. $\mathrm{p}<0.05$ was considered as statistically significant.

\section{Results}

The linearity graph was designed on the LC-MS/MS device, and $\mathrm{R}^{2}$ was found as 0.998 . Measurement of serum creatinine was linear from $0.039 \mathrm{mg} / \mathrm{dL}$ up to $10 \mathrm{mg} / \mathrm{dL}$ in mass spectrometric method.

Inter- and intra-assay precision and bias values were presented in Table 1. CV and bias values were ranged between 1.9-3.8 and 2-15\%, respectively (Table 1).

Creatinine was stable on the bench-top for 15, 30 and 45th days and not changed with three freeze-thaw cycles (results were presented in Table 2) compared with the total allowable error of creatinine $(15 \%)$ on the westgard website [10]. Matrix effects were found between 7.8 and $14.1 \%$ for various creatinine concentrations. Recoveries were $98-101 \%$ for different serum creatinine concentrations (Table 2). 
Table 1: Results of intra- and inter-assay precision (CV\%) and accuracy (Bias\%) studies.

\begin{tabular}{|c|c|c|c|c|c|c|c|c|}
\hline \multirow[t]{2}{*}{ Creatinine concentrations, $\mathrm{mg} / \mathrm{dL}$} & \multicolumn{4}{|c|}{ Intra-assay precision $(n=20)$} & \multicolumn{4}{|c|}{ Inter-assay precision $(\mathrm{n}=\mathbf{2 0})$} \\
\hline & 0.12 & 1.00 & 1.19 & 4.16 & 0.12 & 1.00 & 1.19 & 4.16 \\
\hline Mean & 0.14 & 0.98 & 1.11 & 4.01 & 0.09 & 0.94 & 1.15 & 4.21 \\
\hline SD & 0.004 & 0.027 & 0.024 & 0.076 & 0.003 & 0.033 & 0.035 & 0.09 \\
\hline $\mathrm{CV}, \%$ & 3.2 & 2.8 & 2.2 & 1.9 & 3.8 & 3.6 & 3.1 & 2.3 \\
\hline Bias, \% & 2 & 2 & 8 & 15 & 3 & 6 & 4 & 5 \\
\hline
\end{tabular}

According to our LC-MS/MS measurement results, bias $\%$ values were found as 2.78, 4.77 and $2.15 \%$ for cefazolin, glucose and ceftriaxone, respectively. The bias values for cefazolin, ceftriaxone and glucose were found to be 2.90 , 2.20 and $3.10 \%$ in the enzymatic method and 26, 5.60 and $4.25 \%$ in the jaffe method, respectively. Carryover was determined as $0.003 \mathrm{mg} / \mathrm{dL}$.

The results of our reference range verification study were found to be within the reference range. The rate of non-compliance was determined to be $0 \%$ in males and $10 \%$ in females. The reference intervals of serum creatinine were found to be as $0.8-1.3 \mathrm{mg} / \mathrm{dL}$ for adult males $(\mathrm{n}=20)$, and $0.6-1.1 \mathrm{mg} / \mathrm{dL}$ for adult females $(\mathrm{n}=20)$.

The comparison of the pre-dialysis $(\mathrm{n}=20)$ and postdialysis $(n=20)$ serum creatinine levels was presented in Figure 1. Median (minimum-maximum) pre-dialysis/postdialysis serum creatinine concentrations were 6.8 (4.110.1)/2.0 (1.2-3.1); 7.7 (3.8-11.2)/2.2 (1.4-3.6); 6.5 (3.9-9.8)/ $2.2(1.1-3.2) \mathrm{mg} / \mathrm{dL}$ for enzymatic, Jaffe and mass spectrometric methods, respectively (Figure 1).

Correlation coefficients were 0.990 (95\% confidence interval 0.984-0.993), 0.992 (95\% confidence interval 0.988-0.995) and 0.994 (95\% confidence interval 0.9910.996) for LC-MS/MS-Enzymatic, LC-MS/MS-Jaffe and

Table 2: Results for recovery, freze and thaw, matrix effect and stability studies.

\begin{tabular}{|c|c|c|c|c|}
\hline \multirow{2}{*}{$\begin{array}{l}\text { Creatinine } \\
\text { levels }\end{array}$} & \multirow{2}{*}{$\begin{array}{r}\text { Recovery, } \\
\%\end{array}$} & \multirow{2}{*}{$\begin{array}{r}\text { Matrix } \\
\text { effect, } \\
\%\end{array}$} & \multicolumn{2}{|c|}{ Stability study } \\
\hline & & & $\begin{array}{r}\text { Bias (\%) for } \\
45 \text { day and } \\
0 \text { day differ- } \\
\text { ence }\end{array}$ & $\begin{array}{r}\text { Bias (\%) for } \\
\text { freeze- } \\
\text { thaw for } \\
\text { four cycles }\end{array}$ \\
\hline $\begin{array}{l}\text { Low } \\
\qquad(0.25 \mathrm{mg} / \\
\mathrm{dL})\end{array}$ & 98 & 14.1 & -2.84 & -2.64 \\
\hline $\begin{array}{l}\text { Middle } \\
\qquad(1 \mathrm{mg} / \mathrm{dL})\end{array}$ & 101 & 7.8 & -3.26 & -2.81 \\
\hline $\begin{array}{l}\text { High } \\
\qquad(10 \mathrm{mg} / \\
\mathrm{dL})\end{array}$ & 98 & 11.7 & -0.35 & -2.49 \\
\hline
\end{tabular}

Enzymatic-Jaffe, respectively. Regression equations were found as Enzymatic $=0.06+1.03$ Mass spectrometric, Jaffe $=0.08+$ Mass spectrometric and Jaffe $=-0.008+0.98$ Enzymatic. According to Bland-Altman comparison, negative bias values between mass spectrometry-Jaffe and mass spectrometry-enzymatic methods were as 16.4 and $16.8 \%$, respectively (Figure 2 ).

The LOD (limit of detection), determined by the signal to noise ratio in LC-MS/MS for creatinine, was found to be $0.019 \mathrm{mg} / \mathrm{dL}$. The limit of quantitation (LOQ), determined by the signal to noise ratio in LC-MS/MS for creatinine, was found to be $0.039 \mathrm{mg} / \mathrm{dL}$. A sample chromatogram with $0.25 \mathrm{mg} / \mathrm{dL}$ serum creatinine and $\mathrm{d}_{3}$-creatinine was presented in Figure 3.

CKD-EPI eGFR values were calculated for dialysis patients and presented as Figure 4.

\section{Discussion}

The main outcome of this study was to validate a mass spectrometric serum creatinine method for use in clinical laboratory. The secondary outcome was to compare routine enzymatic and Jaffe methods in either healthy population or patients with dialysis. In our study, method validation for serum creatinine in LC-MS/MS was completed according to CLSI rules, and a comparison of the results obtained by measuring 130 samples, 20 pre- and 20 post-dialysis, 30 in the reference range (normal), 30 with serum creatinine values below the reference range (lower) and 30 above the reference range (higher) was conducted with the enzymatic, mass spectrometric and Jaffe creatinine methods. Early detection of chronic kidney diseases may prevent end-stage renal failure via drug therapies. Accurate measurement of serum creatinine levels is diagnostic for kidney failure [11]. In their study on the validity of urine creatinine levels, Zahoor et al. [12] determined the intra- and inter-assay precision values between 2.8 and $4.1 \%$. Linearity assays were designed to detect higher concentrations due to the related matrix (urine). In our study, validation was performed for serum creatinine 

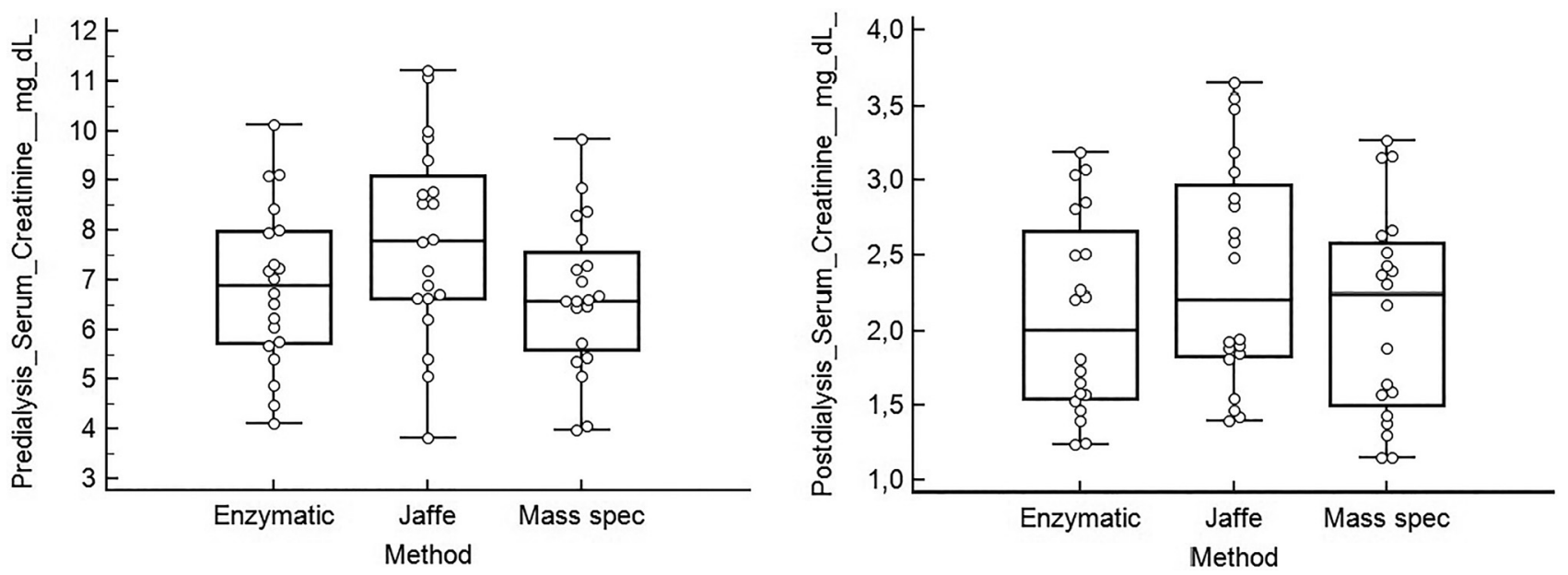

Figure 1: Comparison of pre- (left graph) and post- (right graph) dialysis serum creatinine levels with three methods. $Y$ axis refers to serum creatinine values $(\mathrm{mg} / \mathrm{dL})$.

measurement. The method was found to be linear up to $10 \mathrm{mg} / \mathrm{dL}$ and it was not necessary to perform linearity studies for serum creatinine concentrations higher than $10 \mathrm{mg} / \mathrm{dL}$, since clinically higher concentrations were unlikely to occur. According to their results, mean bias between tandem mass and enzymatic creatinine methods were statistically significant $(0.54 \%)$. Urine matrix is free of protein and other interferences that are found naturally in the serum. In our study we found the bias levels between 2 and $15 \%$. It has been reported that enzymatic creatinine measurement is much more expensive and less prone to interferences compared to Jaffe. Schmidt et al. [13] reported no systematic difference between these methods. In our study, the difference between these two methods was found to be $0.1 \%$. According to Bland-Altman comparison, negative bias values between mass spectrometry-Jaffe and mass spectrometry-enzymatic methods were as 16.4 and $16.8 \%$, respectively (Figure 2). According to Bland Altman analysis, Jaffe and enzymatic methods are not comparable with tandem mass creatinine measurements especially for serum creatinine levels under $0.5 \mathrm{mg} / \mathrm{dL}$. Because measurements were found over 1.96 SD lines at this point. But for the concentrations over $0.5 \mathrm{mg} / \mathrm{dL}$ serum creatinine levels, both methods are in agreement with tandem mass. For both Jaffe and enzymatic creatinine measurement, the results are in confidence interval limits, a negative trend of differences proportional to the magnitude of the measurement can be evaluated according to the comparison with tandem mass spectrometric creatinine results. The bias seems to change with concentration, becoming lower when the concentration is higher. Also Jaffe and enzymatic creatinine methods seem to be comparable for the serum creatinine concentrations over $0.25 \mathrm{mg} / \mathrm{dL}$. An exponential distributions can be detected for lower serum creatinine levels such as under $0.5 \mathrm{mg} / \mathrm{dL}$. The discrepancy between enzymatic, Jaffe and mass spectrometry is much higher for lower serum creatinine values (Figure 2). Harlan et al. [14] found total precision values for mass spectrometric serum creatinine method as $<6 \%$. The average recovery was $107.5 \%$. In our study, intra and inter-assay CV values are similarly between 1.9 and $3.8 \%$ (Table 1 ). Recoveries were 98-101\% for different serum creatinine concentrations. Also, a slope value of 1.07 and intercept of -0.04 with a $r=1$ correlation coefficient were reported for mass spectrometric-Roche enzymatic creatinine assay according to Passing Bablok regression analysis. In our study, these values were found similar to Enzymatic $=0.06+1.03$ Mass spectrometric; $r=0.990$ for Beckman enzymatic creatinine assay. Fernando $J$ et al. [15] compared ADVIA serum enzymatic and kinetic Jaffe creatinine assays and reported a positive bias as $+14.1 \%$ between these methods. In contrast to their findings, there was non-significant positive $0.1 \%$ bias for these two methods in this study. Also, Cheuiche et al. [16] found a correlation coefficient of 0.81 between Roche enzymatic and Jaffe-based creatinine measurement. In this study a good correlation $(r=0.99)$ was detected for Beckman enzymatic and Jaffe assays. Askenazi et al. [17] designed a study to compare the stability of serum creatinine and concluded that serum creatinine was stable for over one-year period. Also, in this study, the stability for 45 days was searched and comparable bias $(<2.84 \%)$ was found. Allegeart et al. [18] reported that enzymatic serum creatinine levels were significantly lower than Jaffe method. Dilute and shoot procedure was defined for the determination of urinary creatinine [19] and comparison of Jaffe and tandem mass spectrometry methods 

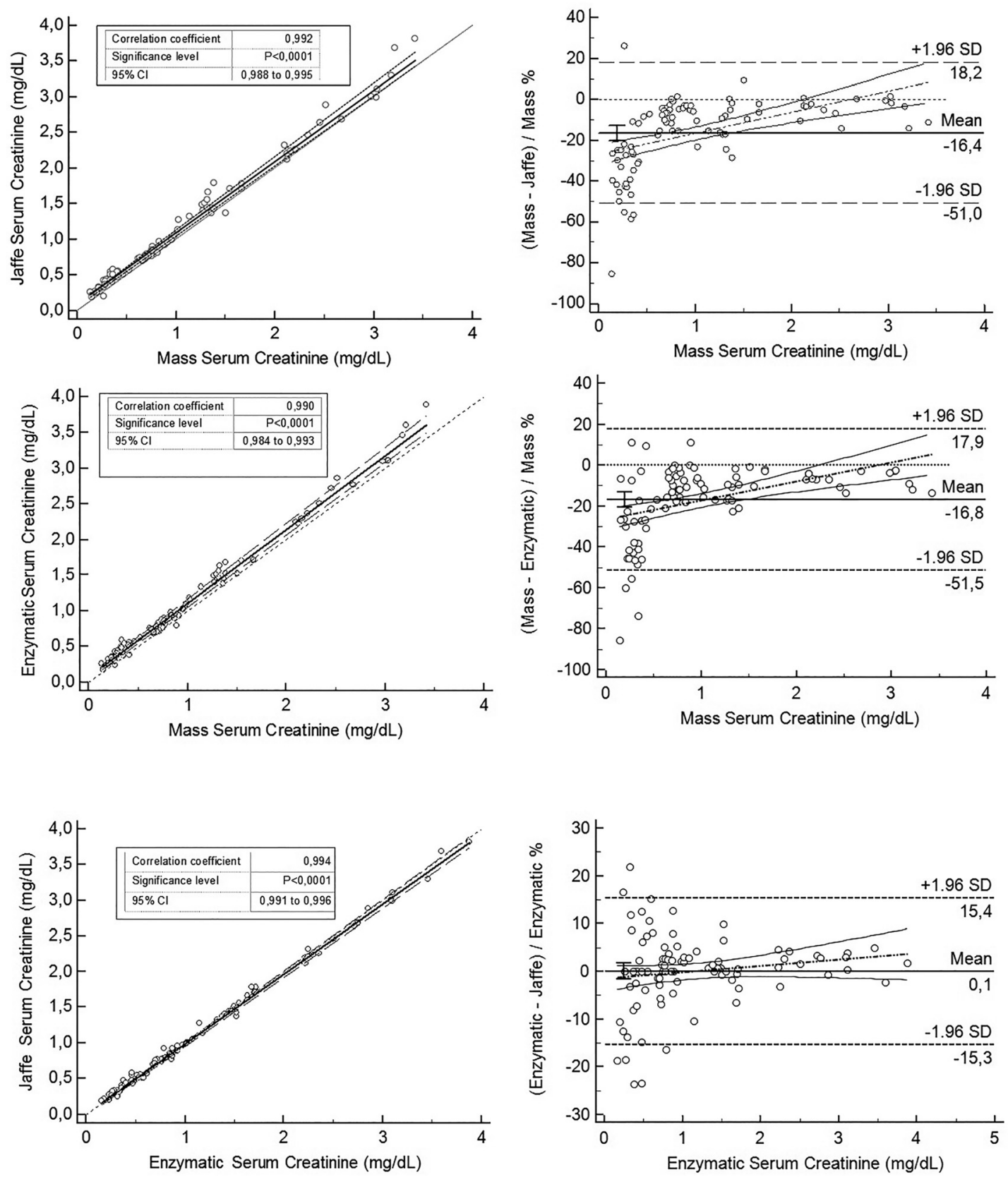

Figure 2: Method comparison of the Creatinine with (1) Passing-Bablok regression and (2) Bland-Altman analysis of Correlation between LCMS/MS and Enzymatic methods, LC-MS/MS and Jaffe methods, Enzymatic and Jaffe methods.

give satisfactory results $\left(\mathrm{R}^{2}=0.91\right)$. Also, in our study there was a good agreement for serum Jaffe and mass spectrometry creatinine methods $\left(\mathrm{R}^{2}=0.99\right)$. Hétu et al. [20] validate a serum creatinine method on tandem mass with methanol precipitation and compared this method by using 36 patient samples with Roche enzymatic assay. Deming regression presented a good correlation and Bland Altman graphics resulted with a mean relative bias of $4.3 \%$. Mean bias in this study for enzymatic and mass spectrometric assays were $-16.8 \%$ (Figure 2). Küme et al. [21] reported that Jaffe method gave higher creatinine results than the enzymatic method, especially at the low levels in both serum and urine. Also, in this study it was presented that there was significant difference up to $25 \%$ below serum concentrations lower than $0.5 \mathrm{mg} / \mathrm{dL}$ (Figure 2). This might be an important issue in specific populations with low serum creatinine levels such as pediatric and gestational patients. Assays using the Jaffe 


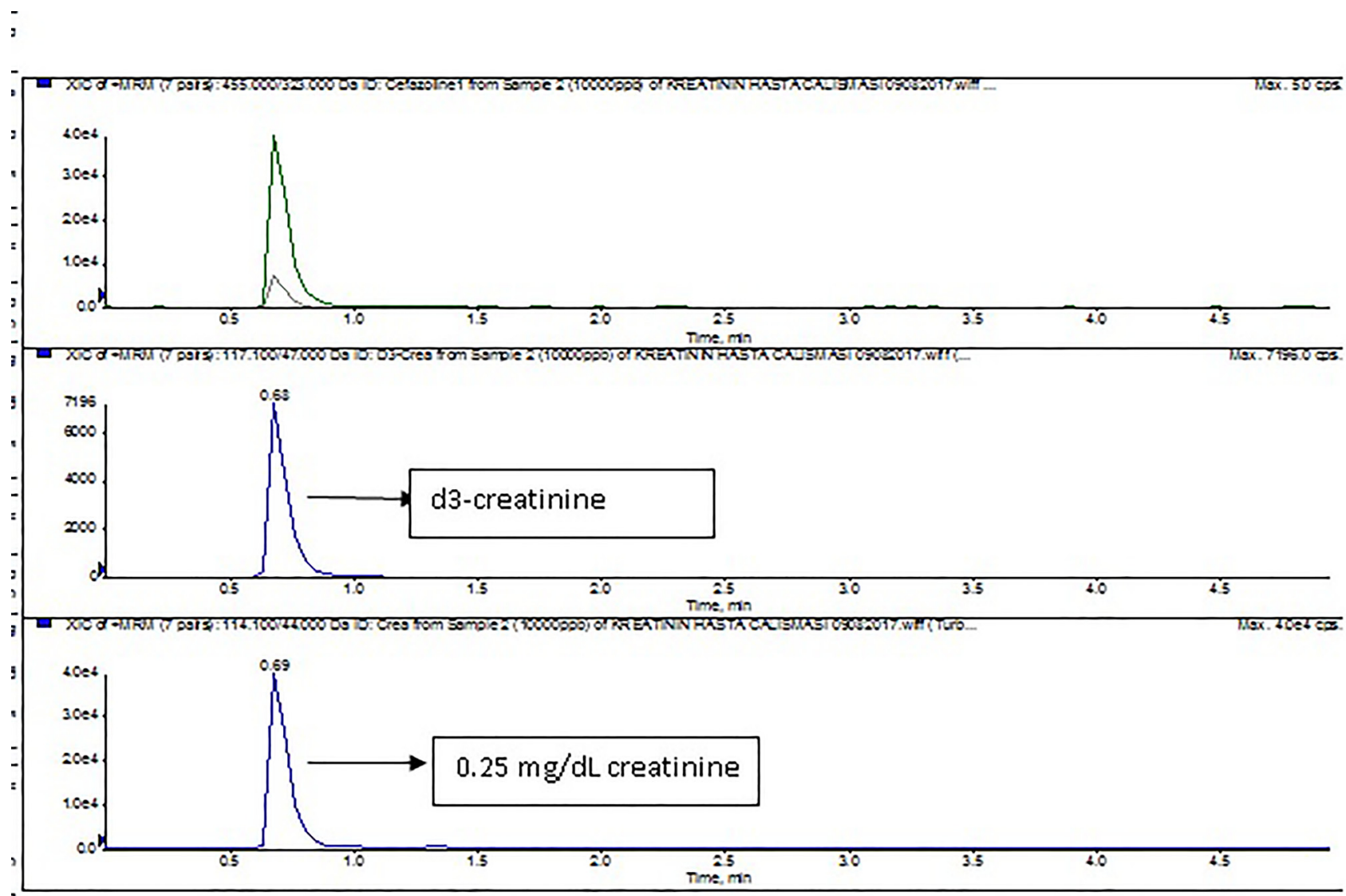

Figure 3: Chromatogram of a patient sample with $0.25 \mathrm{mg} / \mathrm{dL}$ serum creatinine and $\mathrm{d}_{3}$-creatinine isotope.

method for serum creatinine may give $15-25 \%$ higher results due to endogenous interferences [22]. To identify this effect on mass spectrometry, due to structural similarity, glucose, ceftriaxone and cefazolin were selected and tested in this method. Bias\% values were found as 2.78, 2.15 and $4.77 \%$ for cefazolin, ceftriaxone and glucose, respectively. $\mathrm{Ou} \mathrm{M}$ et al. [23] reported that Mindray enzymatic and Jaffe methods demonstrated a mean proportional difference
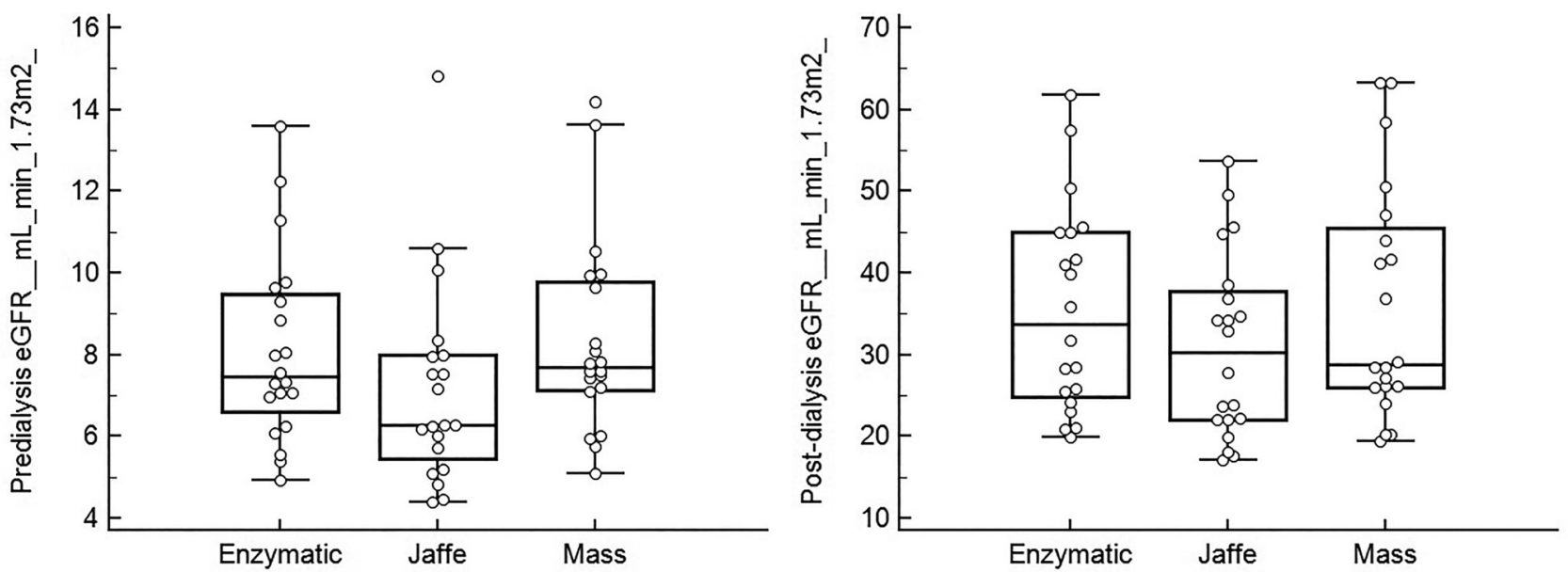

Figure 4: Comparison of pre- (left graph) and post- (right graph) dialysis CKD-EPI eGFR values with three methods. $Y$ axis refers to CKD-EPI eGFR values $\left(\mathrm{mL} / \mathrm{min} / 1.73 \mathrm{~m}^{2}\right)$. 
of -2.1 and $11.7 \%$, respectively, compared with LC-MS/MS. In this study, also we found a negative bias of $16.4 \%$ for mass spectrometric and Beckman Jaffe methods. On the other hand, the difference was higher for Jaffe and mass spectrometric methods (Figure 2). Liu W et al. [24] performed a study with 126 dialysis patients, the mean creatinine levels were found higher in mass spectrometry $(9.51 \mathrm{mg} / \mathrm{dL})$ and lower in enzymatic method $(8.82 \mathrm{mg} / \mathrm{dL})$ compared to Jaffe $(9.01 \mathrm{mg} / \mathrm{dL})$. In contrast to their results, the lowest levels of serum creatinine for 20 pre-dialysis patients were found in mass spectrometric our study (Figure 1). Owen LJ et al. [25] reported the limit of quantitation value in mass spectrometry as $0.056 \mathrm{mg} / \mathrm{dL}$. In this study, we found the LOQ as 0.039 with a signal to noise ratio 10. Major limitation of our study was the lack of NIST SRM 967a creatinine sample for measurement. Also, reference range was verified in this study instead of defining.

In conclusion, the implementation of LC-MS/MS may provide more accurate test results with high sensitivity and specificity in specific patient populations. In this study, a practical, fast and simple method with a protein precipitation step was applied to clinical laboratory. If an interference is found (such as cefazolin etc.) or suspected (especially border-line or unexpected abnormal creatinine elevations), mass spectrometric determination may be an alternative solution with its high selectivity and specificity. Although, Jaffe method for serum creatinine measurement is still much more practical and cheap so in use for routine practice, tandem mass spectrometric detection of serum creatinine can be used as an accurate and specific method for verification of discordant clinical results, existence of possible interferences and serum levels under $0.5 \mathrm{mg} / \mathrm{dL}$ creatinine results such as pediatric or pregnant populations.

Acknowledgments: This study was supported by Selcuk University Scientific Research Projects Organization (Project number: 16202033).

Conflict of interest: None declared.

\section{References}

1. Levey AS, Inker LA. GFR as the "gold standard"67:9-12.

2. Delanaye $P$, Cavalier E, Pottel H. Serum creatinine: not so simple! Nephron 2017;136:302-8.

3. Bargnoux AS, Kuster N, Cavalier E, Piéroni L, Souweine JS, Delanaye P, et al. Serum creatinine: advantages and pitfalls. J Lab Precis Med 2018;3:71.

4. Tsikas D, Wolf A, Frölich JC. Simplified HPLC method for urinary and circulating creatinine. Clin Chem 2004;50:201-203.
5. Zhao Y, Liu G, Angeles A, Christopher LJ, Wang Z, Arnold ME, et al. $A$ validated $L C-M S / M S$ method for the quantitative measurement of creatinine as an endogenous biomarker in human plasma. Bioanalysis 2016;8:1997-2005.

6. Fraselle S, De Cremer K, Coucke W, Glorieux G, Vanmassenhove J, Schepers E, et al. Development and validation of an ultra-high performance liquid chromatography-tandem massspectrometry method to measure creatinine in human urine. J Chromatogr B Analyt Technol Biomed Life Sci 2015;988:88-97.

7. Nakano M, Uemura O, Honda M, Ito T, Nakajima Y, Saitoh S, et al. Development of tandem mass spectrometry-based creatinine measurement using dried blood spot for newborn mass screening. Pediatr Res 2017;82:237-243.

8. Fernández-Fernández $M$, Rodríguez-González P, Añón Álvarez ME, Rodríguez F, Menéndez FV, Alonso JIG, et al. Simultaneous determination of creatinine and creatine in human serum by double-spike isotope dilution liquid chromatography-tandem mass spectrometry (LC-MS/MS) and gas chromatography-mass spectrometry (GC-MS). Anal Chem 2015;87:3755-3763.

9. Clinical \& Laboratory Standards Institute: CLSI Guidelines. httpss://clsi.org/standards.htm. [Accessed July 2018].

10. Westgard QC. Desirable biological variation database specifications. httpss://www.westgard.com/biodatabase1.htm. [Accessed Nov 2016].

11. Dodder NG, Tai SS, Sniegoski LT, Zhang NF, Welch MJ. Certification of creatinine in a human serum reference material by GC-MS and LC-MS. Clin Chem 2007;53:1694-1699.

12. Zahoor N, Uliana D, Hubert WV. A fully automated high-throughput liquid chromatography tandem mass spectrometry method for measuring creatinine in urine. Clin Mass Spect 2019;11:1-7.

13. Schmidt RL, Straseski JA, Raphael KL, Adams AH, Lehman CM. A risk assessment of the Jaffe vs Enzymatic method for creatinine measurement in an outpatient population. PLoS One 2015;10: e0143205.

14. Harlan R, Clarke W, Di Bussolo JM, Kozak M, Straseski J, Meany DL. An automated turbulent flow liquid chromatography-isotope dilution mass spectrometry (LC-IDMS) method for quantitation of serum creatinine. Clin Chim Acta 2010;411:1728-1734.

15. Fernando JH, María JL, Aida P, Fernández M, Sagastagoia O, Magadán C. Comparison between ADVIA Chemistry systems Enzymatic Creatinine_2 method and ADVIA Chemistry systems Creatinine method (kinetic Jaffe method) for determining creatinine. Scand J Clin Lab Investig 2004;74:629-636.

16. Cheuiche AV, Soares AA, Camargo EG, Weinert LS, Camargo JL, Silveiro SP. Comparison between IDMS-traceable Jaffe and enzymatic creatinine assays for estimation of glomerular filtration rate by the CKD-EPI equation in healthy and diabetic subjects. Clin Biochem 2013;46:1423-1429.

17. Askenazi DJ, Moore JF, Fineberg N, Koralkar R, Clevenger S, Sharer JD. Comparison of methods, storage conditions, and time to analysis of serum and urine creatinine measured from microsamples by liquid chromatography mass spectrometery (LC/MS) vs. Jaffe. J Clin Lab Anal 2014;28:405-408.

18. Allegaert K, Kuppens M, Mekahli D, Levtchenko E, Vanstapel F, Vanhole $C$, et al. Creatinine reference values in ELBW infants: impact of quantification by Jaffe or enzymatic method. J Matern Fetal Neonatal Med 2012;25:1678-1681.

19. Niesser M, Koletzko B, Peissner W. Determination of creatinine in human urine with flow injection tandem mass spectrometry. Ann Nutr Metab 2012;61:314-321. 
20. Hétu PO, Gingras ME, Vinet B. Development and validation of a rapid liquid chromatography isotope dilution tandem mass spectrometry (LC-IDMS/MS) method for serum creatinine. Clin Biochem 2010;43:1158-1162.

21. Küme T, Sağlam B, Ergon C, Sisman AR. Evaluation and comparison of Abbott Jaffe and enzymatic creatinine methods: Could the old method meet the new requirements? J Clin Lab Anal 2018;32. https://doi.org/10.1002/jcla.22168.

22. Nah H, Lee SG, Lee KS, Won JH, Kim HO, Kim JH. Evaluation of bilirubin interference and accuracy of six creatinine assays compared with isotope dilution-liquid chromatography mass spectrometry. Clin Biochem 2016;49:274-81.
23. Ou M, Song Y, Li S, Liu G, Jia J, Zhang M, et al. LC-MS/MS method for serum creatinine: comparison with enzymatic method and Jaffe method. PLoS One 2015;10:e0133912.

24. Liu WS, Chung YT, Yang CY, Lin CC, Tsai KH, Yang WC, et al. Serum creatinine determined by Jaffe, enzymatic method, and isotope dilution-liquid chromatography-mass spectrometry in patients under hemodialysis. J Clin Lab Anal 2012;26:206-214.

25. Owen LJ, Wear JE, Keevil BG. Validation of a liquid chromatography tandem mass spectrometry assay for serum creatinine and comparison with enzymatic and Jaffe methods. Ann Clin Biochem 2006;43:118-123. 